UCRL 8024

UNIVERSITY OF CALIFORNIA

Radiation

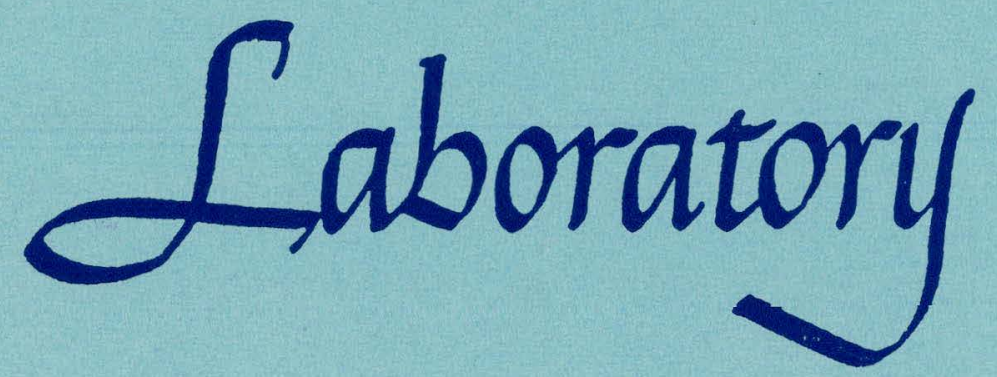

LOCALIZATION OF CERIUM-I44

IN THE SKELETAL TISSUES

OF FETAL RATS

BERKELEY, CALIFORNIA 


\section{DISCLAIMER}

This report was prepared as an account of work sponsored by an agency of the United States Government. Neither the United States Government nor any agency Thereof, nor any of their employees, makes any warranty, express or implied, or assumes any legal liability or responsibility for the accuracy, completeness, or usefulness of any information, apparatus, product, or process disclosed, or represents that its use would not infringe privately owned rights. Reference herein to any specific commercial product, process, or service by trade name, trademark, manufacturer, or otherwise does not necessarily constitute or imply its endorsement, recommendation, or favoring by the United States Government or any agency thereof. The views and opinions of authors expressed herein do not necessarily state or reflect those of the United States Government or any agency thereof. 


\section{DISCLAIMER}

Portions of this document may be illegible in electronic image products. Images are produced from the best available original document. 
This report was prepared as an account of Government sponsored work. Neither the United States, nor the Commission, nor any person acting on behalf of the Commission:

A. Makes any warranty or representation, express or implied, with respect to the accuracy, completeness, or usefulness of the information contained in this report, or that the use of any information, apparatus, method, or process disclosed in this report may not infringe privately owned rights; or

B. Assumes any liabilities with respect to the use of, or for damages resulting from the use of any information, apparatus, method, or process disclosed in this report.

As used in the above, "person acting on behalf of the Commission" includes any employee or contractor of the Commission to the extent that such employee or contractor prepares, handles or distributes, or provides access to, any information pursuant to his employment or contract with the Commission. 
UCRL- 8024

Biology and Medicine

\section{UNIVERSITY OF CALIFORNIA}

Radiation Laboratory

Berkeley, California

Contract No. W-7405-eng-48

LOCALIZATION OF CERIUM- 144 IN THE SKELETAL TISSUES OF FETAL RATS

C. Willet Asling, Muriel E. Johnston, Patricia W. Durbin, and Joseph G. Hamilton

October 18, 1957

Printed for the U.S. Atomic Energy Commission 


\title{
LOCALIZATION OF CERIUM-144 IN THE SKELETAL TISSUES OF FETAL RATS
}

C. Willet Asling, Muriel E. Johnston, Patricia W. Durbin, and Joseph.G. Hamilton

Crocker Laboratory

University of California

Berkeley, California

October 18, 1957

\begin{abstract}
The developing fetal skeleton of the rat was used to study the microscopic localization of the rare earth $\mathrm{Ce}^{144}$ in bone. Nineteen-day-old rat fetuses were injected with Ce 144 in isotonic sodium citrate via the umbilical vein. They were sacrificed one-half hour after the injection by immersion in $80 \%$ alcohol fixative. The fetuses were embedded in paraffin and sectioned at 10 to $12 \mu$. Semiserial sections were treated with periodic acidSchiff stain for mucopolysaccharides, and by the von Kossa technique for calcium. Contact $x-$ ray-film autoradiographs and NTB stripping-film autoradiographs were prepared.

Photographs of representative sections and their respective autoradiographs are presented for various bones. This material strongly suggests that the initial binding site of $\mathrm{Ce}^{144}$ in the skeleton is in the organic matrix of cartilage and bone, especially where this matrix is just entering the calcifiable state. This conclusion is highly dependent upon the specificity of the von Kossa stain for calcium. Further studies are under way to correlate this histochemical test with the autoradiographic demonstration of tracer $\mathrm{Ca}^{45}$.
\end{abstract}




\section{LOCALIZATION OF CERIUM-144 IN THE SKELETAL TISSUES} OF FETAL RATS

C. Willet Asling, Muriel E. Johnston, Patricia W. Durbin, and Joseph G. Hamilton

Crocker Laboratory

University of California

Berkeley, California

October 18, 1957

In rational attempts to decontaminate the body after accidental ingestion of the bone-seeking rare earth elements, a basic consideration is a knowledge of the binding site of these elements in the skeleton. One must know whether these elements have a predilection for the bone-salt apatite, or for the organic matrix, or for cells associated with the bone's formation and metabolism. In general, autoradiographic studies with rare earths have shown localization on bone surfaces in spots corresponding to the centers of Haversian-system or other vascularized regions, and at areas of active new bone formation underlying epiphyseal cartilage plates. Only a few attempts at more refined localization have yielded definitive information. Flawless sections of undecalcified bone of requisite thinness for autoradiography are exceedingly difficult to obtain. The inadequate resolution of contact autoradiographs, and the difficulties of critical differential staining of sections mounted on stripping-film emulsions, have contributed to further uncertainty. In vitro chemical studies of the fixing capacity of organic or inorganic material obtained from bone have yielded more clear-cut information, but by their nature did not duplicate living bone.

In an attempt to meet these objections, the developing (fetal) skeleton has been examined for possible advantages for study. This preliminary report discusses some of the se advantages, and demonstrates the differential localization observed for the lanthanide rare earth, cerium $\left(\mathrm{Ce}^{144}\right)$.

The requirements for the study were fetuses whose skeletons showed areas of maturity varying from hyaline cartilage to fully calcified bone. They must, on the one hand, be mature enough to survive for a reasonable time (more than one-half hour) after removal from the mother's uterus and, on the other hand, be sufficiently immature that flawless serial sections of the entire fetus could be cut in the sagittal plane after paraffin embedding. The 19-day old rat fetus was found to satisfy these requirements (Day 1 = time of finding sperm in vagina of mother). Figure 1 illustrates a typical section through such a fetus, very slightly lateral to the mid-sagittal plane. The regions of special interest are indicated.

The vertebral column was of the greatest interest because, owing to serial development of the individual vertebrae, one may find "bones" in all stages of endochondral developmental transition from hyaline cartilage through to fully ossified cancellous bone. Any single center is composed of only one of these tissues. Centers are separated from one another by 
such great distances that no problems of film-resolving capacity are encountered. From a study of the alizarin-stained skeleton of developing fetuses at half-day age intervals, one may estimate that one new vertebra ossifies approximately every 8 to 12 hours at this age. The calvarium of the skull contains well-separated bones in several stages of intramembranous development. It therefore offers advantages for the study of isotopic uptake during osteogenesis.

The hyoid bone lies approximately perpendicular to the plane of section employed, and is therefore cut in cross section. Thus, in serial sections one passes successively through a complete sequence in the various stages in endochondral osteogenesis, which are more conventionally represented in a single section cut longitudinally.

The special interest attaching to other areas studied (base of the skitl, incisor tooth and its alveolus, sternebrae, and os pubis) will be mentioned in connection with their descriptions.

Nineteen-day-old rat fetuses received injections of $0.1 \mu \mathrm{C}$ of $\mathrm{Ce}^{144}$ in isotonic sodium citrate into the umbilical cord. Subsequently, they were kept alive (heart beating and respiratory movements occurring periodically) for a half hour. Warm moist heat and occasional light pressure assisted in maintaining them. They were then plunged into $80 \%$ alcohol, and fixed for 48 hours; about midway through the fixation period they were hemisected in the median sagittal plane. They were then dehydrated in dioxane for at least 24 hours; and embedded in $56^{\circ}-58.5^{\circ}$ paraffin over a minimum 8 -hour period. Serial sections 10 to $12 \mu$ thick were then autoradiographed either by contact with Eastman Industrial $x$-ray film, Type A, or by mounting on Eastman's $10 \mu$ NTB stripping film. The series of autographs and subsequent stains were so planned that the structural and histochemical features of the tissue producing any of the autographs could be revealed by the stain either on that section or an adjacent section. The following stains were applied: hematoxylin and eosin, von Kossa silver nitrate method for calcium, and the Hotchkiss-McManus periódic-acid-Schiff (PAS) stain for mucupulysaccharides.

Several regions of the vertebral column are instructive. Figure $2 a$ shows (from above downward) the lst, 2 nd, and $3 \mathrm{rd}$ thoracic vertebrae $(T-1-3)$. The ossification centers in the bodies or centra should not be confused with the developing intervertebral joints. The latter are ovoid and empty except for the developing nucleus pulposus; the former are lacy in structure. Ossification centers are seen only in $\mathrm{T}-2$ and $\mathrm{T}-3$, where the cartilage is breaking döwn through erosion of lacunar walls by osteogenic tissue. In $\mathrm{T}-1$ the centrum is still intact hyaline cartilage. The autoradios:graph (Fig. 2b) shows a tiny shadow in $\mathrm{T}-1$ without any corresponding anatomical specialization. In $T-2$ and $T-3$ the autograph appears at the junction line between intact hyaline cartilage and that which is breaking down. Figure 3a, a calcium stain of an adjacent section, shows that T-1 has no calcium deposit despite its cerium uptake. In $T-2$ and $T-3$, despite the heavy calcium deposition in the entire centrum, only the periphery of this tissue shows an autograph (Fig. 3b). 
Figures $4 a, 4 b, 5 a$, and $5 b$ show comparable views of $T-12, T-13$, and L- 1 (first lumbar). One should note gaps in the dorsal (right-hand side) autoradiographic ring of $\mathrm{T}-13$ and $\mathrm{L}-1$, corresponding in the section to the fenestra of the ossification center. where osteogenic tissue is invading the center. Osteogenic tissue per se is thus shown not to have taken up the isotope. The section passes just to one side of this fenestrum in $\mathrm{T}-12$, and hence no gap is shown in section or autograph.

The width of the autoradiographic ring prevents precise localization of the isotope which gave rise to it. In an effort to judge the source of the autograph, the dimensions of the ossification center have been measured in each of the three vertebrae shown fusing the long and short axes of the oval formed by the margin of the calcium deposit), and similarly, the autoradiographic images were measured on both the inner and outer margins of the ring. The loci of mid-points of these rings were then estimated by averaging inner and outer marginal dimensions (see Table I).

Table I

Dimensions of vertebral ossification centers and their radioautographic images.

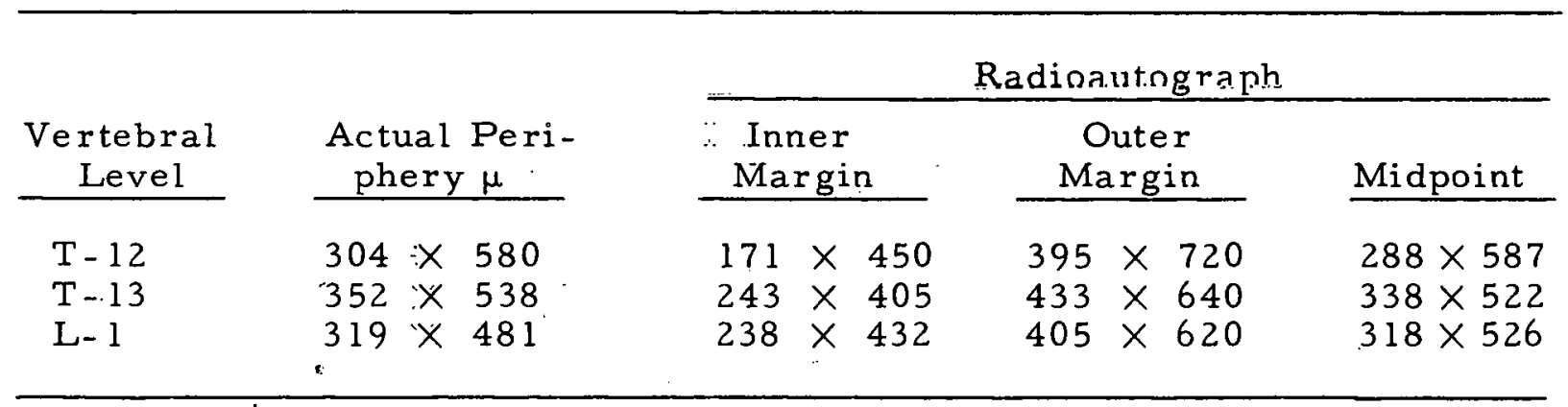

It may be seen that, with allowance for errors in measurement (due chiefly to unsharpness of autoradiographic margins), there is a good correspondence between the margin of the os sification center and the midpoint (presumptive locus of origin) of the autoradiograph. This correspondence alone is, however, subject to the same criticism as information obtained from contact autoradiographs of adult rat bones. In the experi=: ment presented here, it is strongly supported by stripping-film autoradiographs (Figs.6a and 6b), which show clearly that the localization of the cerium was at and just ahead of the calcifying margin.

In Fig. 7a it may be seen that there is substantial calcification in the interparietal and frontal bones and slight calcification:in the caudal part of the parietal bone. In the more rostral part of the parietal bone, calcium deposits are sparse. or lacking, although there is new organic matrix to be found. The autoradiograph (Fig. $7 \mathrm{~b}$ ) is seen in this uncalcified region but not in the calcified bones. 
Although the hyoid bone is still cartilaginous and uncalcified at the section level shown (Fig. 8a), a strong autoradiograph of cerium is to be seen (Fig. $8 \mathrm{~b}$ ). While the basioccipital bone in the same photograph bears the expected surface localization and appears to offer no new information, it should be noted that only one surface (that opposite the cranial cavity) gave rise to an autoradiographic shadow. Were surface apatities alone the predisposing factor, both surfaces should show an image. The image is, however, found only on the extracranial (growing) surface, where new matrix is being formed, and not on the intracranial surface where growth is in abeyance.

Also, in the head one may note the alveolus for the lower incisur tooth (Figs. $9 a$ and $9 b$ ). While there is heavy calcification of bone (and light calcification of the dentine at the tip of the tooth bud), there is no image except for a slight crescent on the deep surface of the caudal margin of the mandible. There was a strongly positive PAS reaction at this site.

The same is true for the os pubis (Figs. 10a and 10b). The crescentic autoradiographic image coincides more with the site of strong PAS reaction than with the mineralized cartilage and bone.

Figures $11 \mathrm{a}$ and $11 \mathrm{~b}$ show that the autoradiograph on the surface of the xiphoid ossification center of the sternum is much longer than the corresponding calcification. Its extent coincides with a thin, noncalcified layer of PAS-positive material just underlying the terminal "buds" of osteogenic periosteum.

\section{Critique}

This study strongly suggests that the initial binding site of the rafe earth $\mathrm{Ce}^{144}$ in the skeleton is in the organic matrix of cartilage and bone, especially where this matrix is just entering its calcifiable state. The: study does not exclude the possibility that the element later binds to the apatite of the mineral component. It would appear, however, that if this occurs it is secondary, since the cerium has shown no tendency here lo bind with substantial deposits of calcium, despite their maximal availability so far as blood supply is concerned.

It is obvious that the foregoing conclusion is dependent on the accuracy and delicacy of the von Kossa silver nitrate test for histochemical localization of calcium deposits. The test is generally accepted as highly specific: Reference to some of the illustrations shown here will establish that extremely thin strands of calcified matrix have been visualized. It is conceivable, although not likely, that apatite deposits may exist that are so scanty and recent that they are not positive histochemically. The

*Such an autograph has also been obtained, in association with similar "buds" at the costochondral junction, with the rare earths promethium-147 and plutonium-239. The autograph of americium-24l was suggestive but not definitive. The alkaline earths calcium-45 and strontium-90 have shown no such deposition (Asling et al., "The Localization of Certain Alkaline and Rare Earth Elements in the Costochondral Juction of the Rat, "Anatomical Record 113, No. 3, July 1952). 
autoradiographic technique as used here on fetuses should lend itself well to testing the specificity of the von Kossa technique by correlating a $\mathrm{Ca}^{45}$ autoradiograph with the histochemical test. Such a study, and further studies with rare earths and with $\mathrm{Sr}^{90}$, are in progress. 


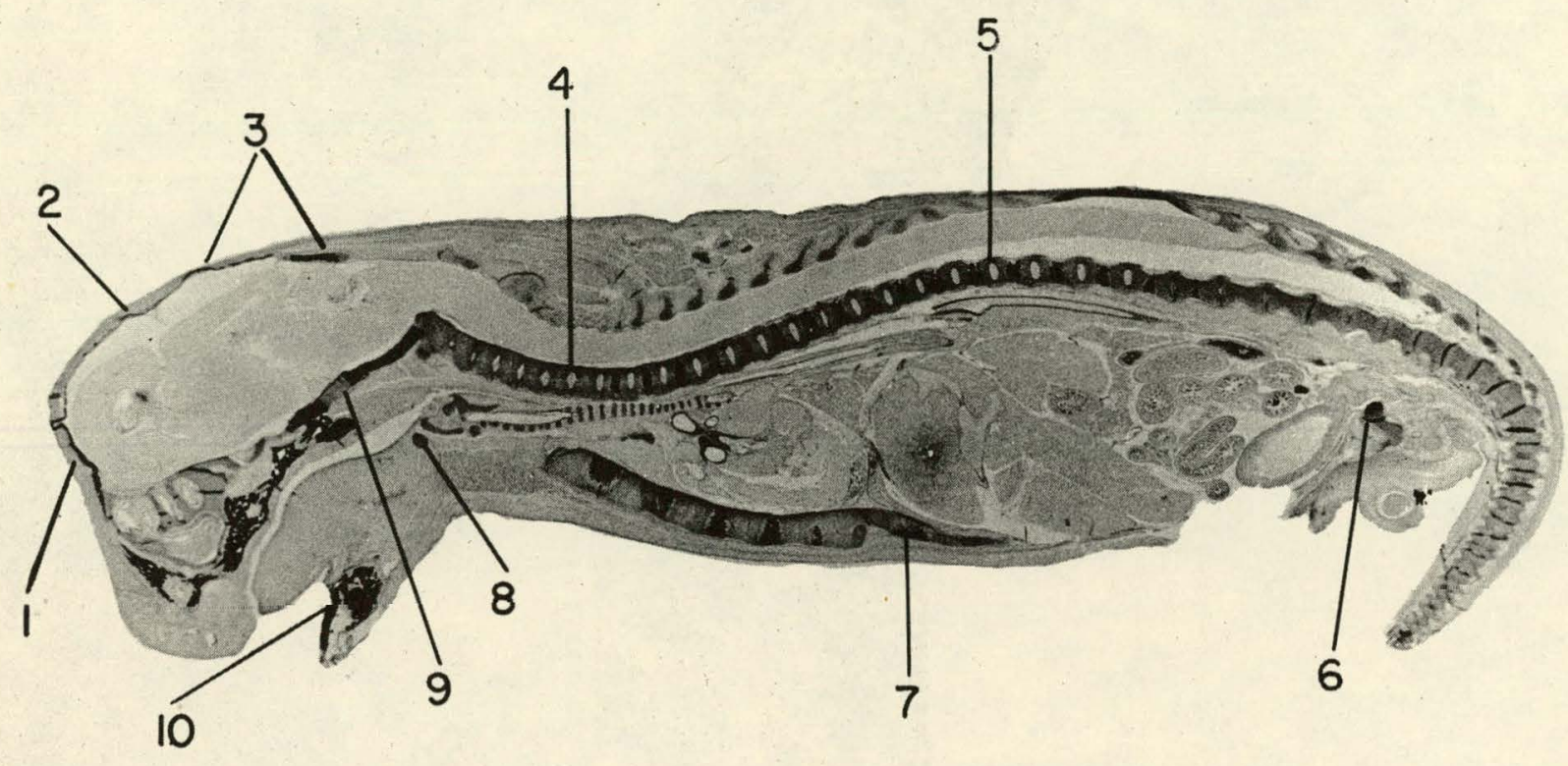

$\mathrm{ZN}-1820$

Fig. 1. Sagittal section, slightly lateral to mid-line, of 19-day old $r$ at fetus, stained for calcium by von Kossa reaction and for mucopolysaccharides by periodic-acid-Schiff stain. $6 x$. 


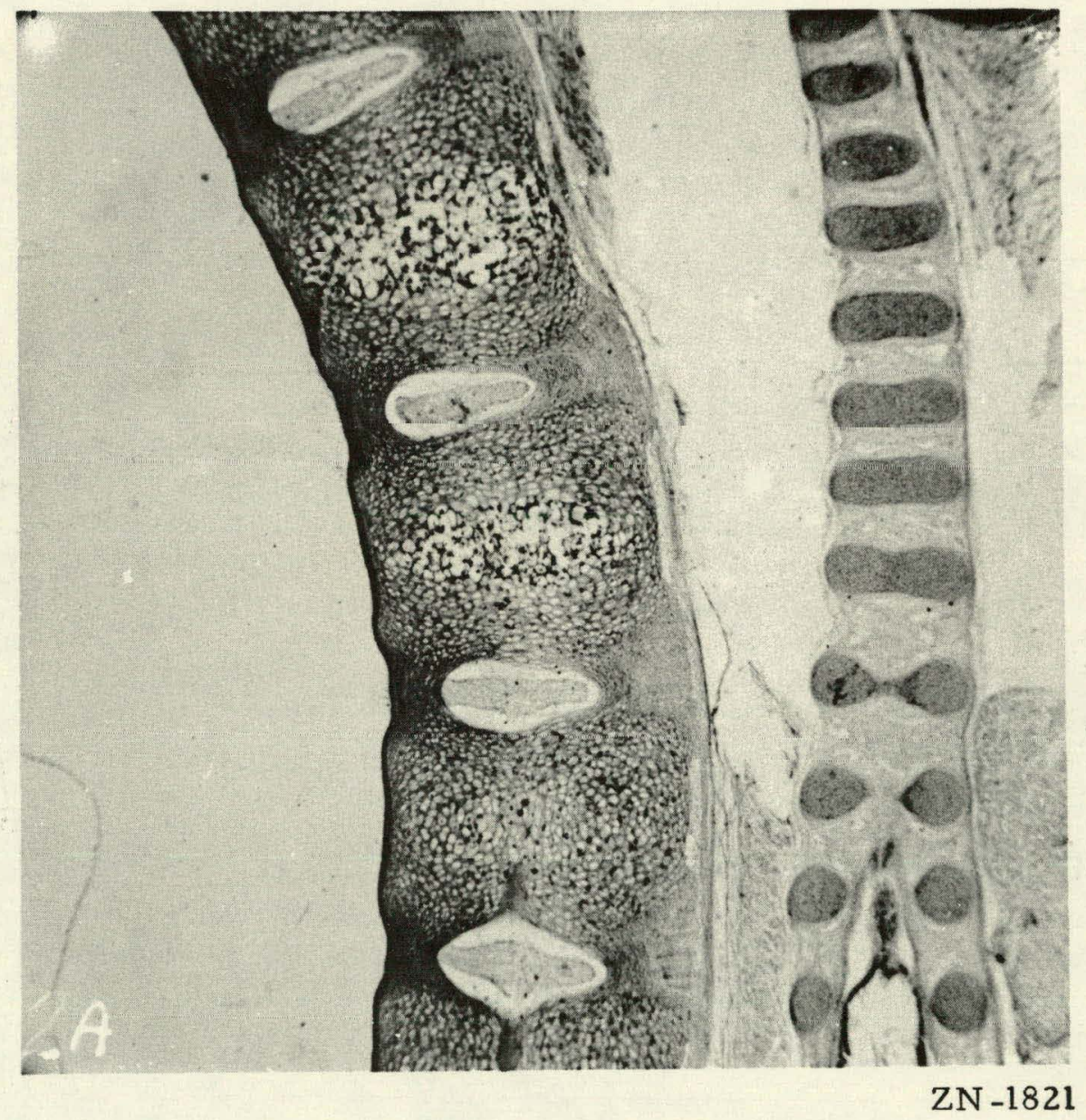

Fig. 2a. Bodies of first to third thoracic vertebrae, PAS stain. 2lx. See region 4, Fig. 1. 


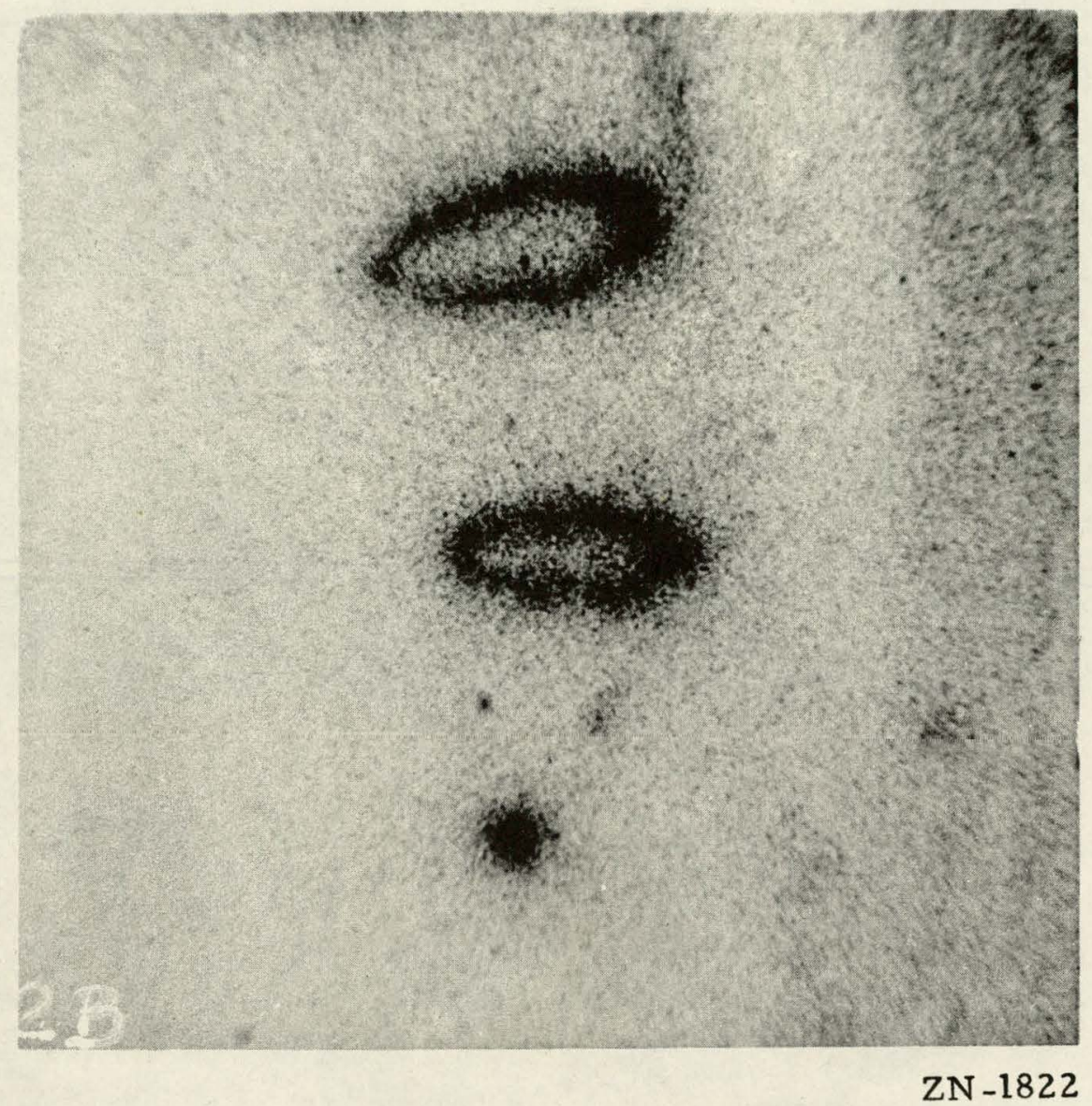

Fig. 2b. Corresponding contact autoradiograph. 


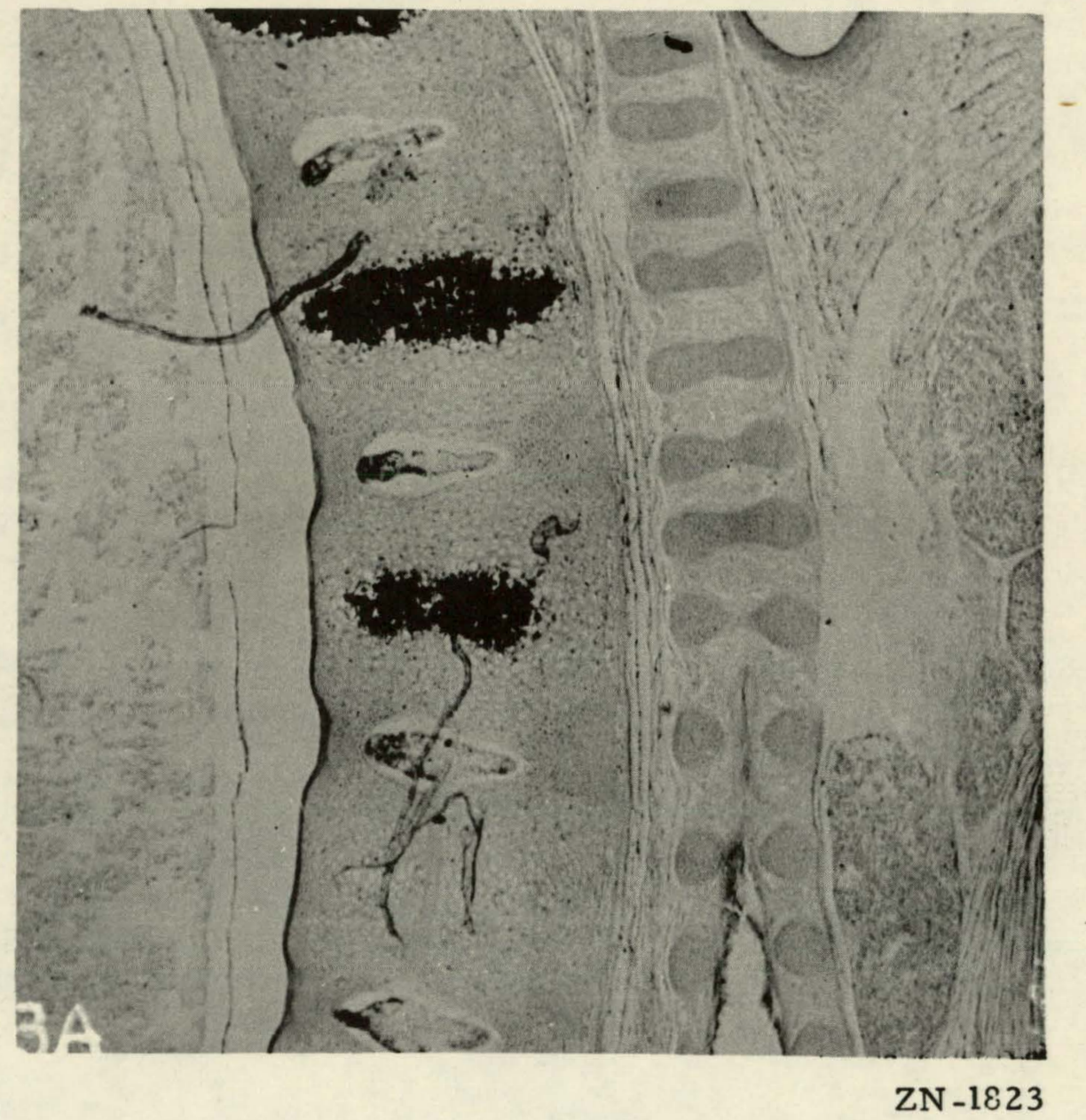

Fig. 3a. Bodies of 1 st to 3rd thoracic vertebrae, von Kossa and PAS stains (the black deposits indicate sites of calcification). $21 x$. See region 4, Fig. 1. 


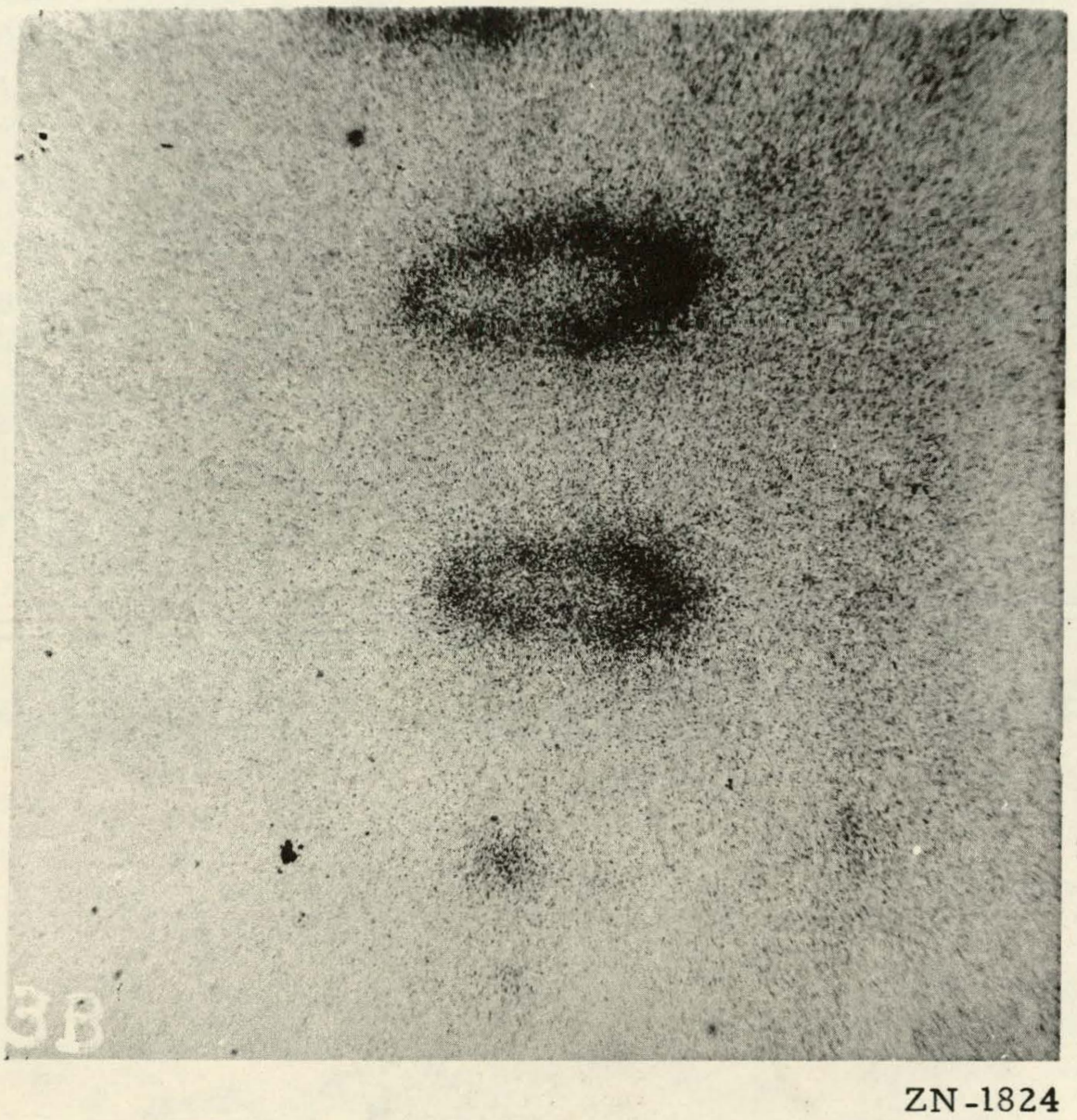

Fig. 3b. Corresponding contact autoradiograph. 


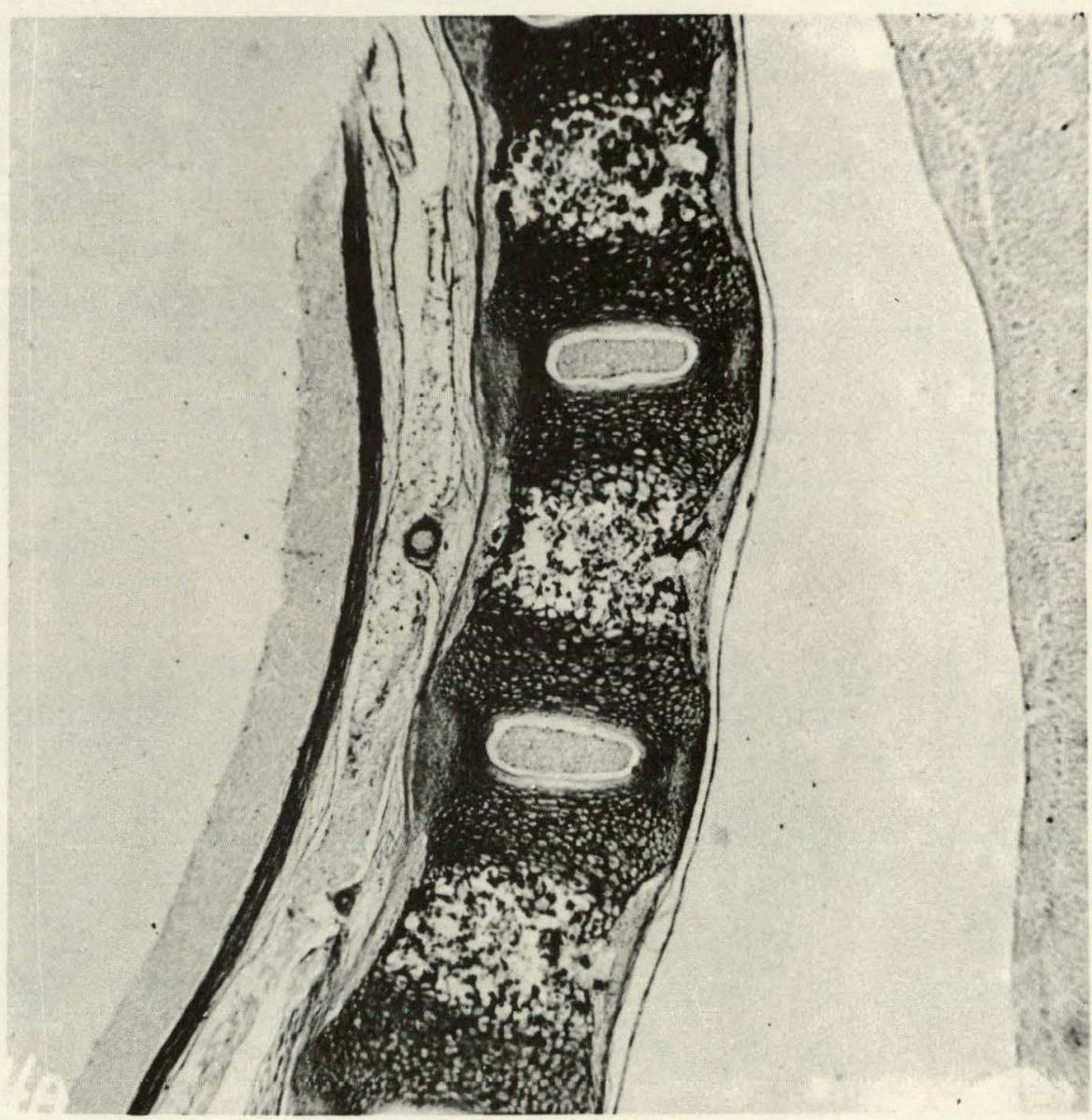

$\mathrm{ZN}-1825$

Fig. 4a. Bodies of 12 th and 13 th thoracic and 1st lumbar vertebrae, PAS stain. 2lx. See region 5, Fig. 1 . 


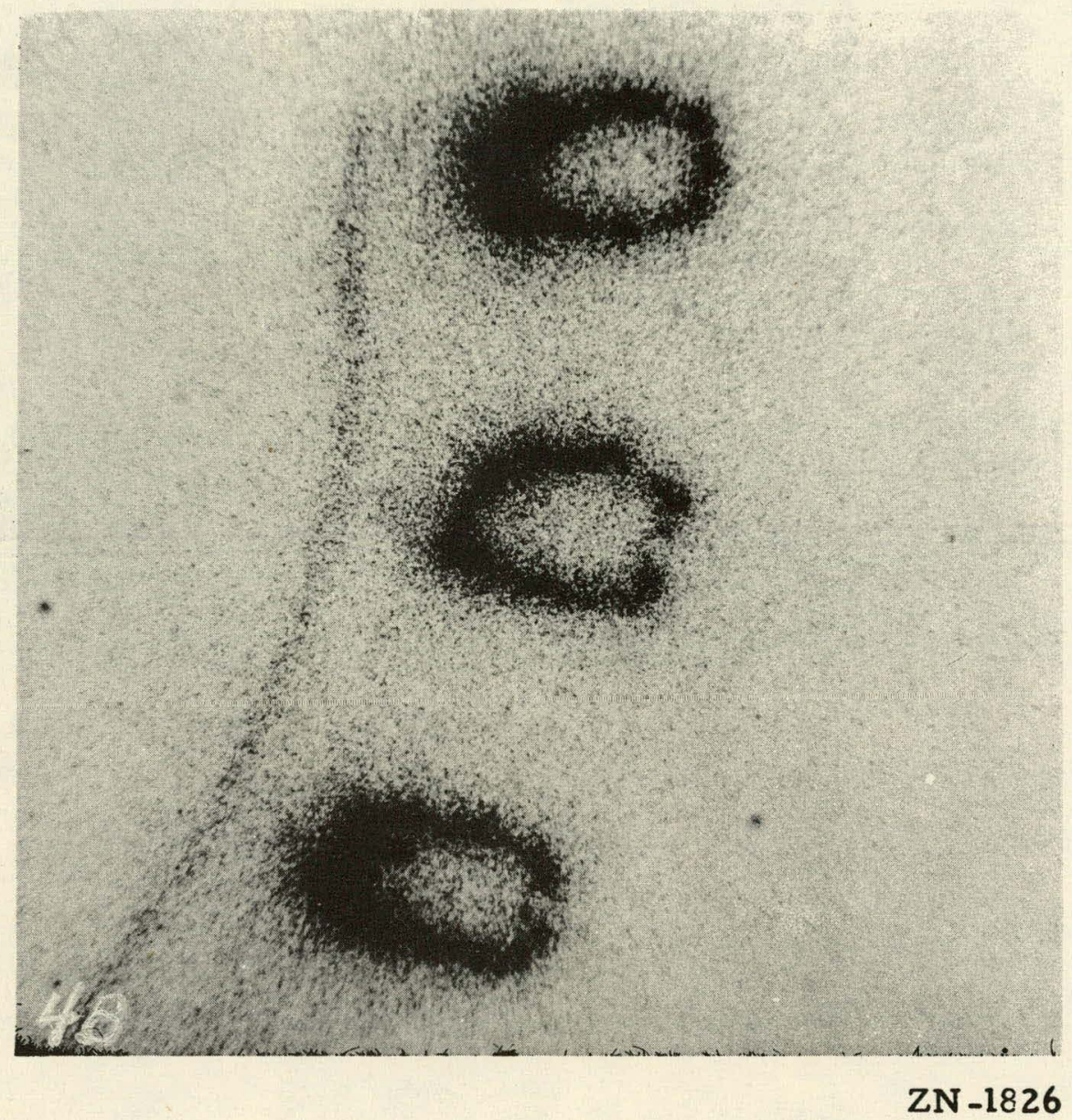

Fig. 4b. Corresponding contact autoradiograph. 


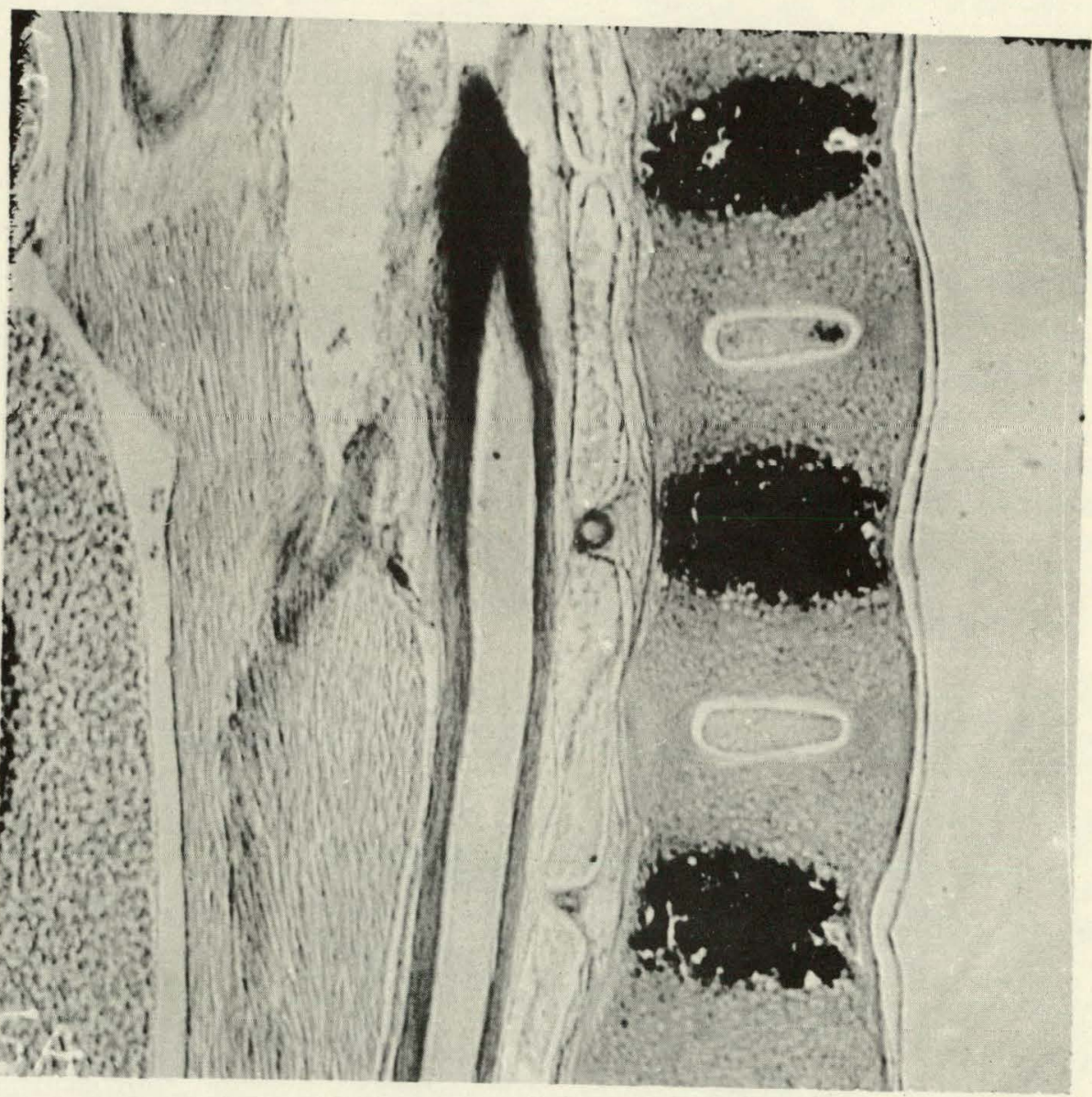

$\mathrm{ZN}-1827$

Fig. 5a. Bodies of 12 th and 13th thoracic and lst lumbar vertebrae, von Kossa and PAS stains. 2lx. See region 5, Fig. 1. 


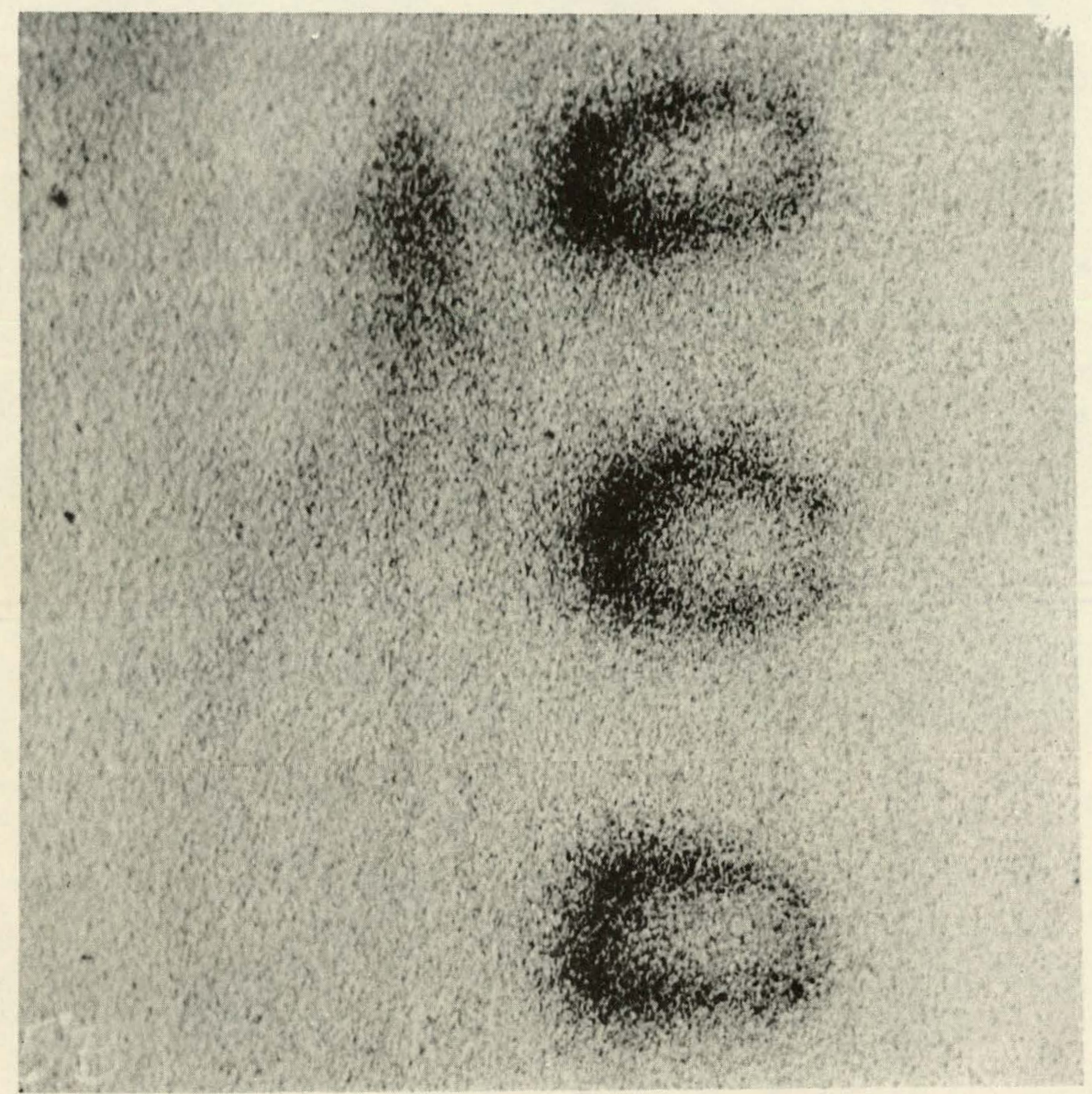

ZN-1828

Fig. 5b. Corresponding contact autoradiograph. 


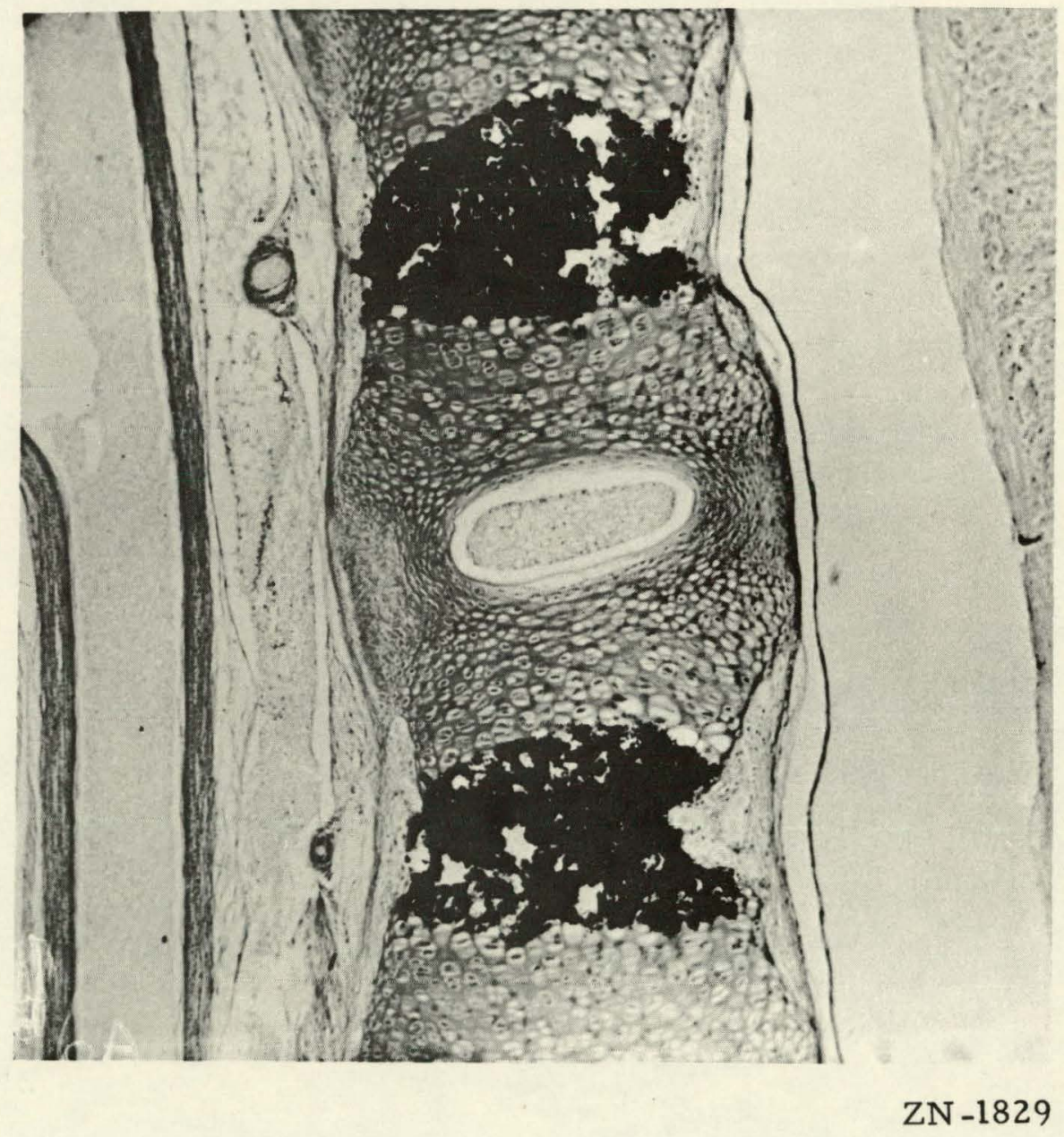

Fig. 6a. Bodies of 13 th thoracic and lst lumbar vertebrae, von Kossa and PAS stains. 35x. See region 5, Fig. 1 . 


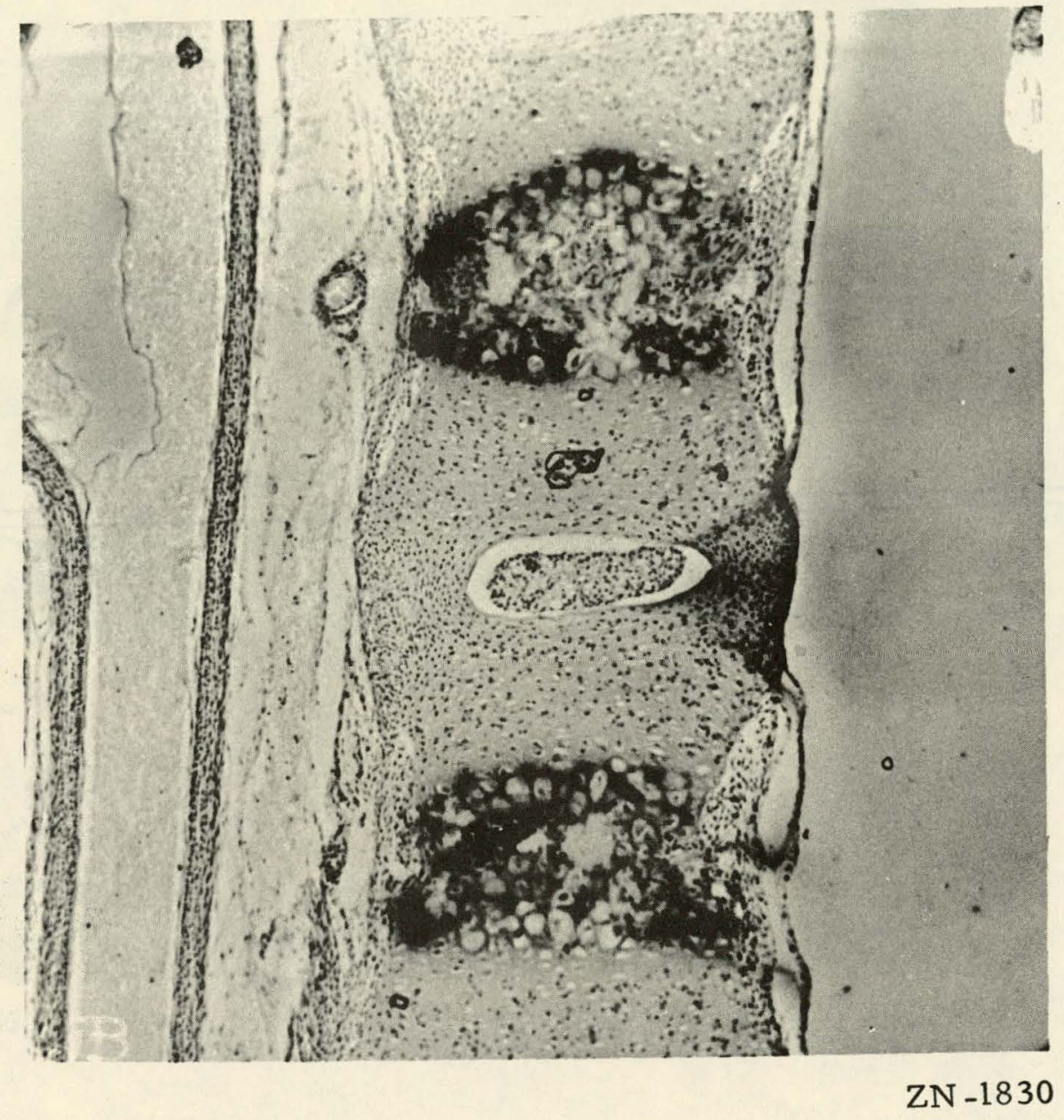

Fig. 6b. NTA stripping-film autoradiograph of section immediately adjacent to that shown in $6 \mathrm{a}$. $\mathrm{H}$ and $\mathrm{E}$ counterstain. $35 \mathrm{x}$. 


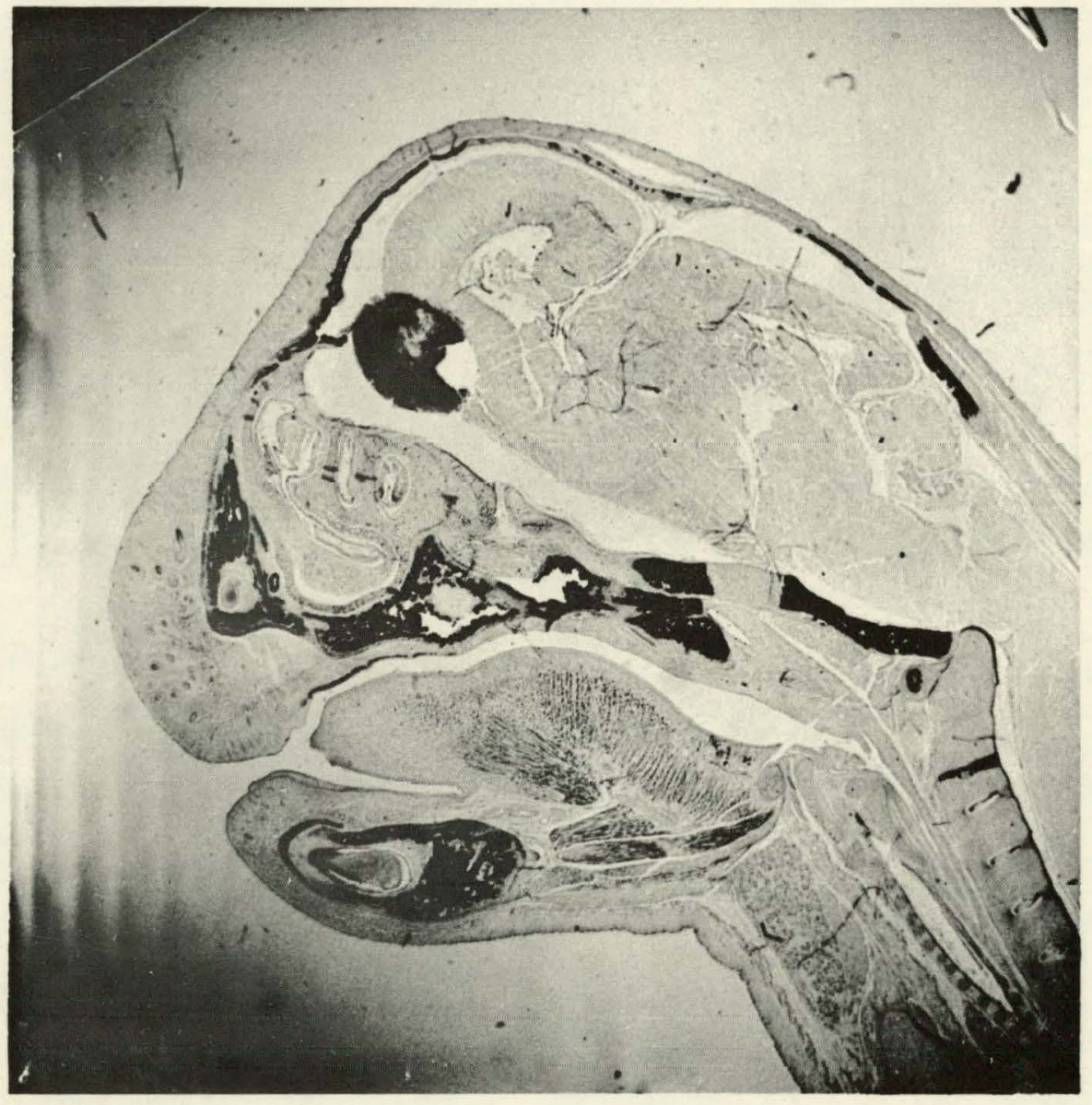

ZN-1831

Fig. 7a. Parasagittal section of head, von Kossa and PAS stains. 5x. Note vault of cranium, corresponding to regions 1, 2, and 3 in Fig. 1. 


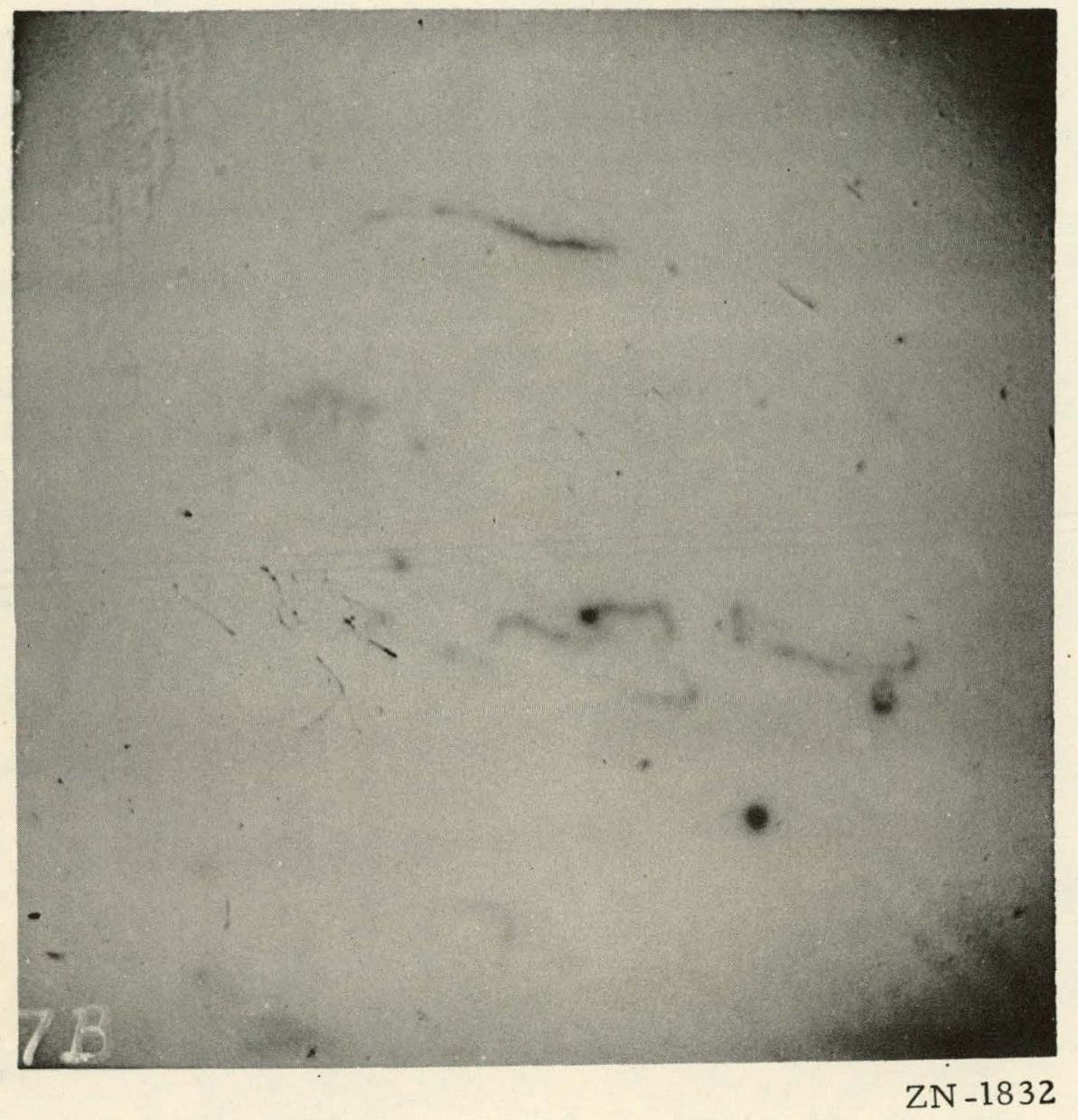

Fig. 7b. Corresponding contact autoradiograph. 


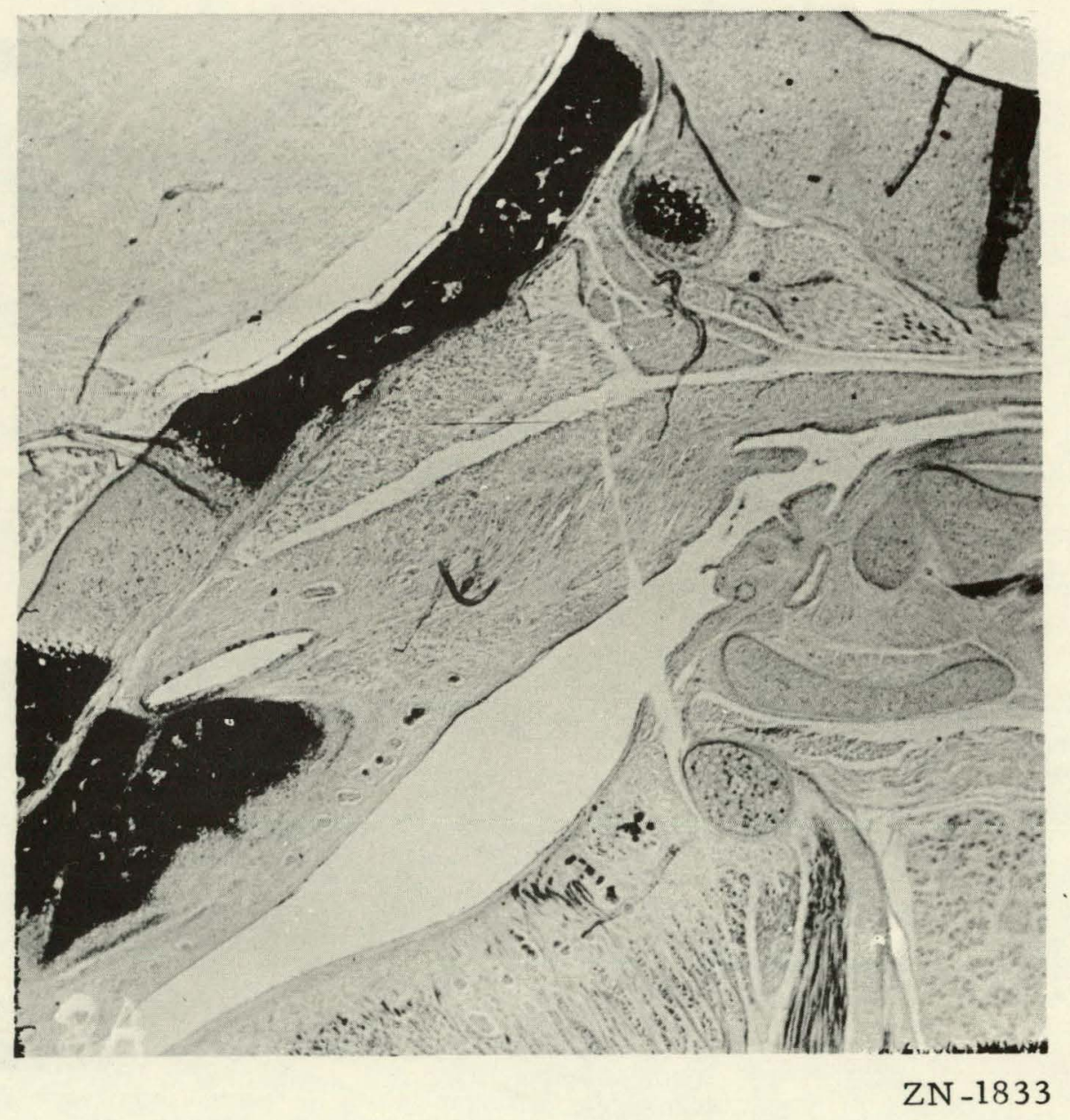

Fig. 8a. Hyoid bone (region 8, Fig. 1) and basicranium (region 9, Fig. 1), von Kossa and PAS stains. 15x. 


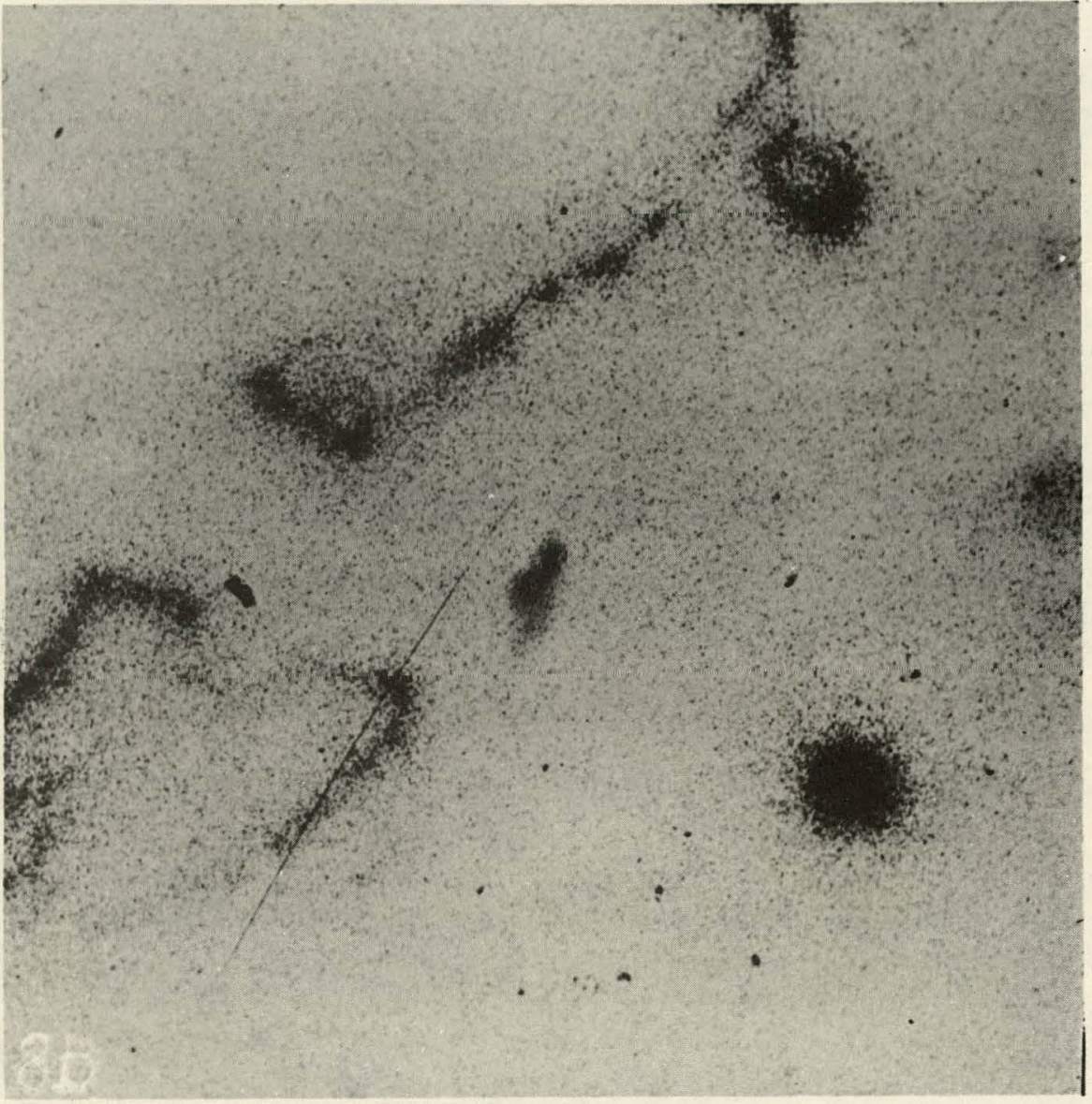

ZN -1834

Fig. 8b. Corresponding contact autoradiograph. 


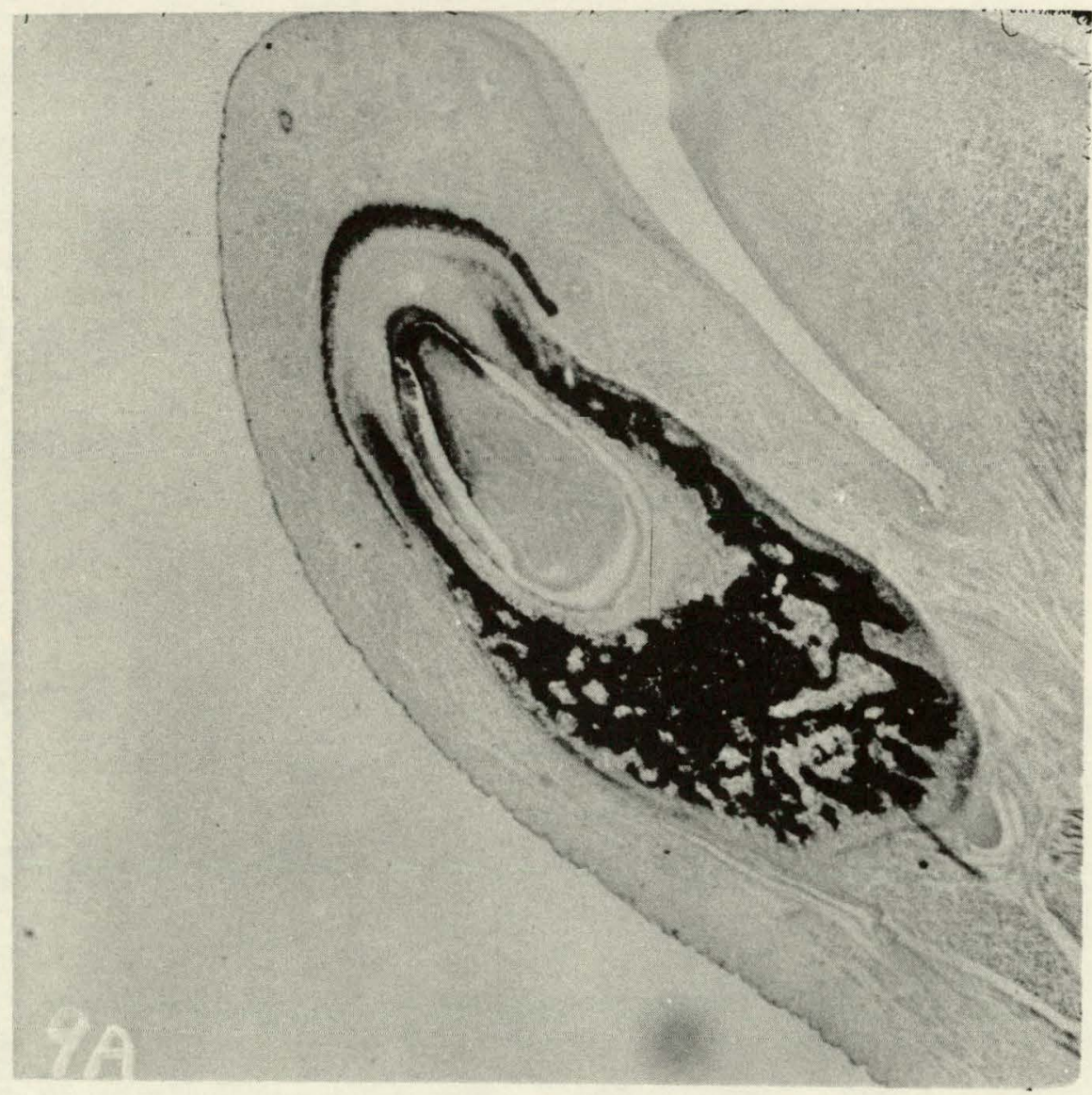

$\mathrm{ZN}-1835$

Fig. 9a. Alveolus of lower incisor tooth, and mandible (region 10, Fig. 1), von Kossa and PAS stains. 15x. 


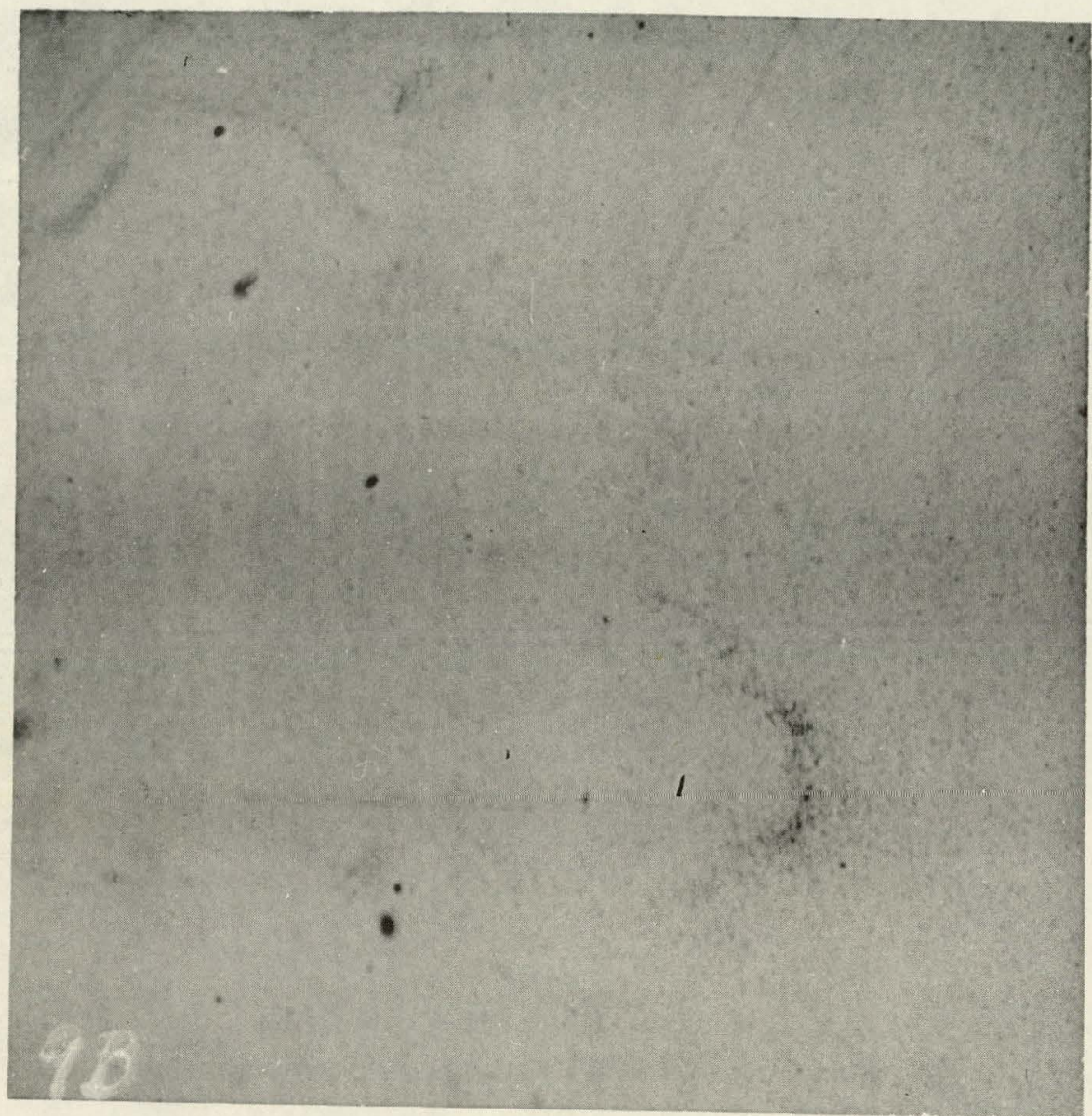

$\mathrm{ZN}-1836$

Fig. 9b. Corresponding contact autoradiograph (slight shadow in lower right corner). 


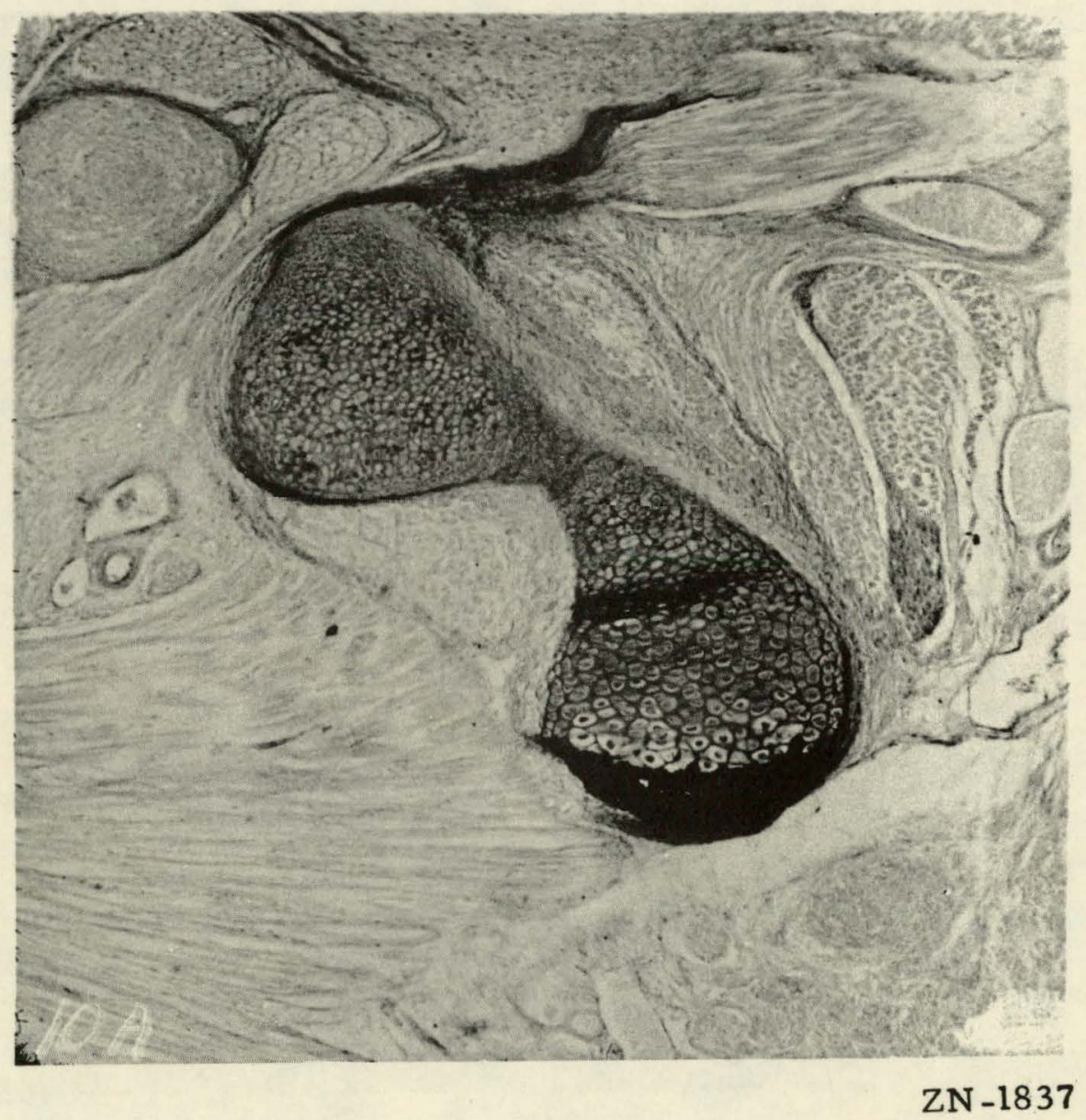

Fig. 10a. Os pubis (region 6, Fig. 1), von Kossa and PAS stains. 35x. 


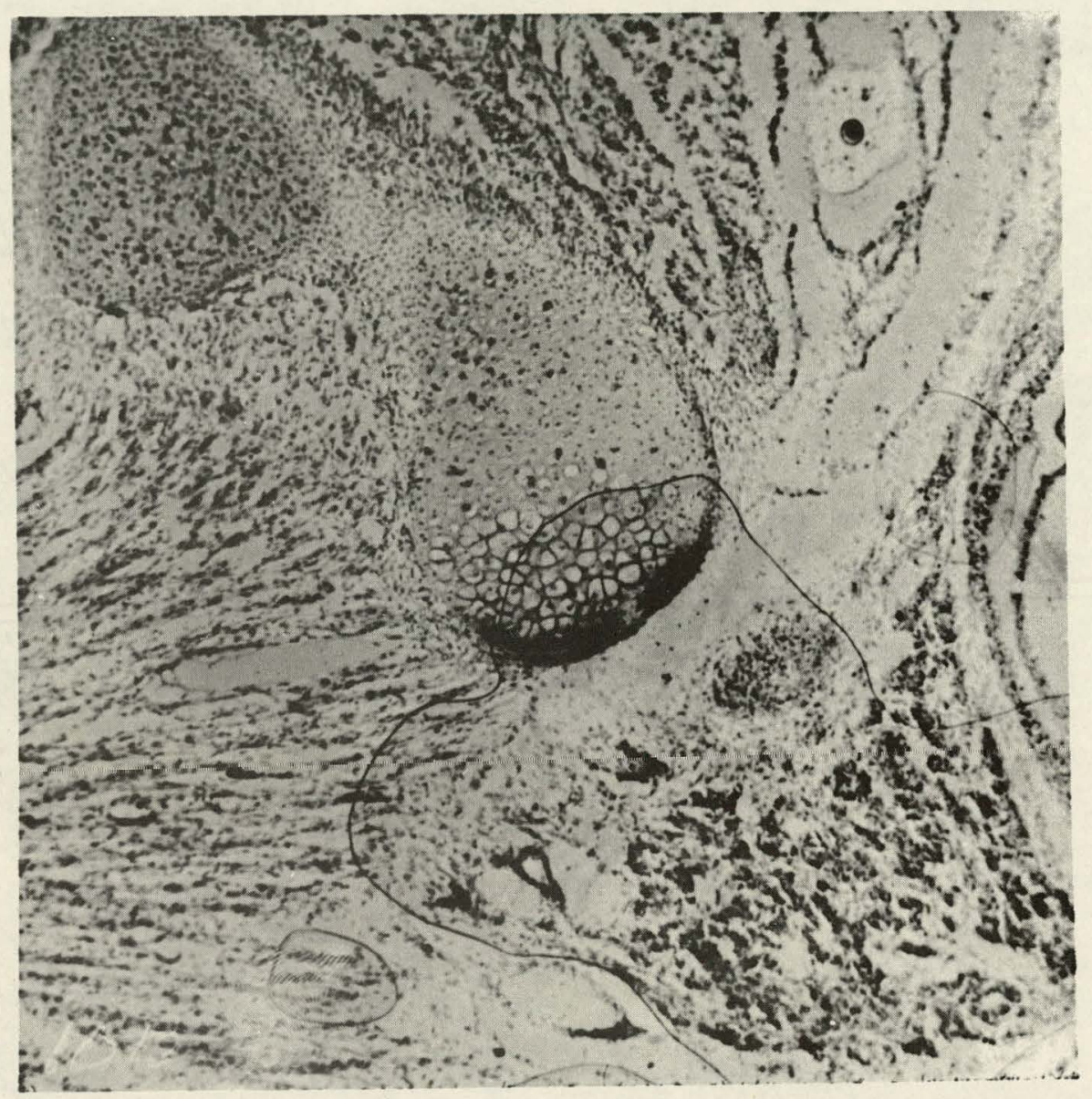

$\mathrm{ZN}-1838$

Fig. 10b. NTA stripping-film autoradiograph of section immediately adjacent to that shown in Fig. 10a. H and E counter stain. 35x. 


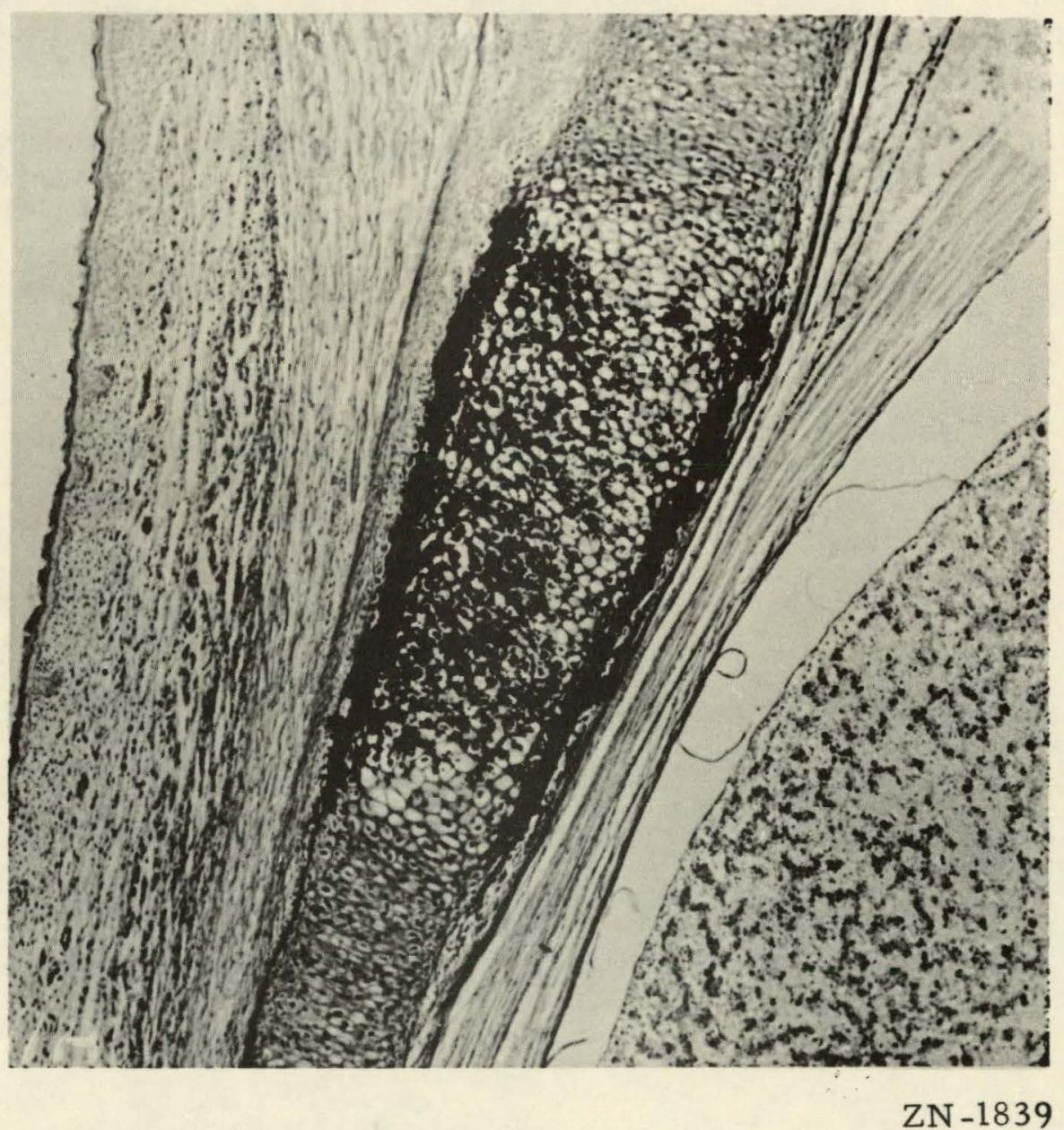

Fig. 1la. Xiphoid process of sternum (region 7, Fig. 1), von Kossa and PAS stains. $35 x$. 


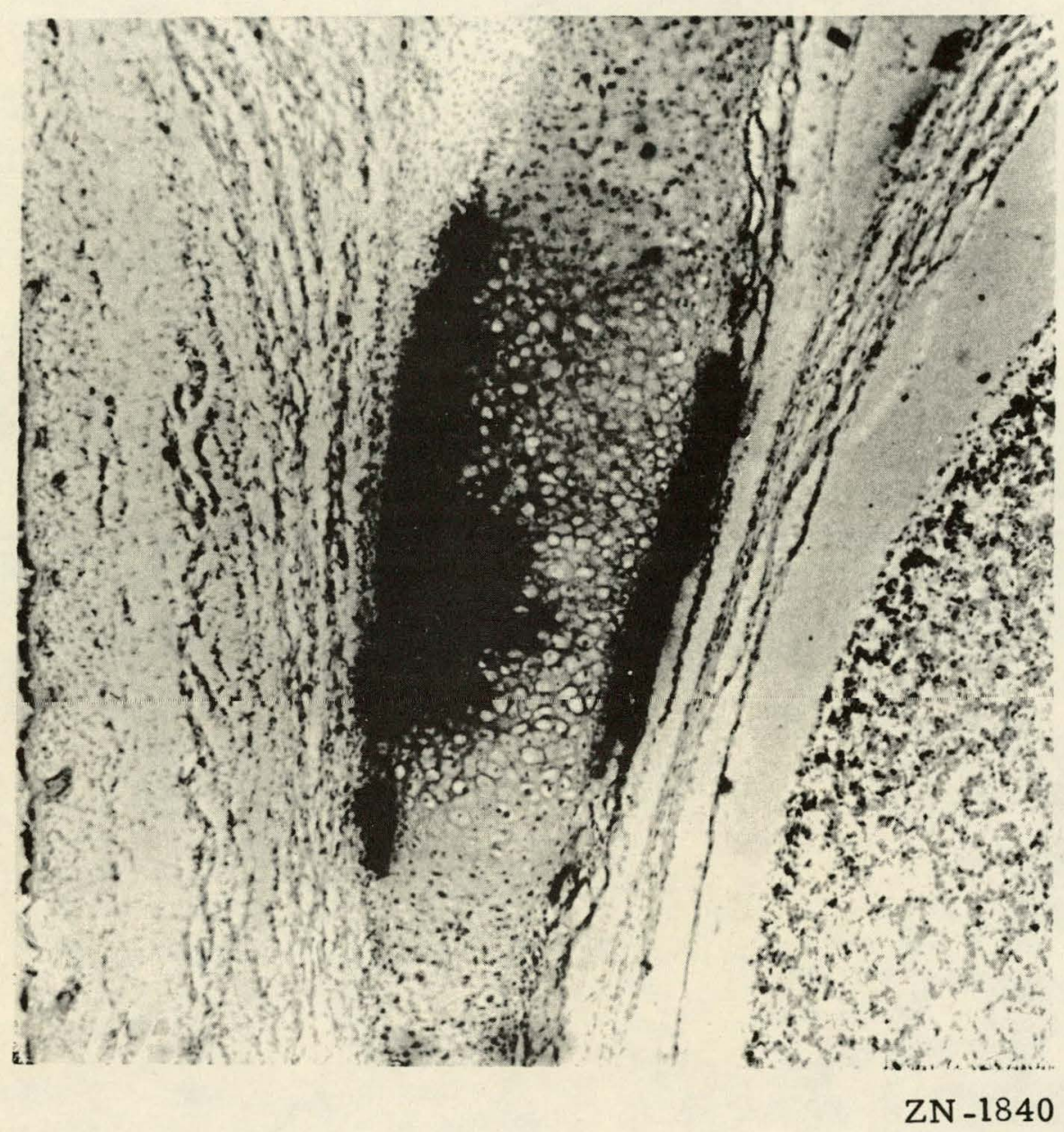

Fig. 1lb. NTA stripping film autoradiograph of section immediately adjacent to that shown in Fig. 1la. $\mathrm{H}$ and E counterstain. 35x. 